Гирник Мария Николаевна

аспирант факультета социально-гуманитарного образования

Краснодарского государственного института культуры

\section{К ВОПРОСУ О ГЕНЕЗИСЕ РОССИЙСКОГО ЛИБЕРАЛИЗМА}

Аннотация:

В статье исследовано влияние закона на формирование гражданского общества. Рассмотрен ряд причин, обусловливающих отсутствие устоявшихся либеральных ценностей в российском обществе. Освещена история либерализма, мыслящего конституцию как документ, гарантирующий и закрепляющий базовые либеральные ценности.

Ключевые слова:

социальный детерминизм, закон, конституционный дух, менталитет, система ценностей, права и свободы личности, либерализм.
Girnik Maria Nikolayevna

PhD student, Social and Liberal Arts Education School, Krasnodar State Institute of Culture

\section{CONCERNING THE GENESIS OF THE RUSSIAN LIBERALISM}

Summary:

The article examines the impact of the law on the formation of the civil society. The author discusses a number of reasons underlying the lack of long-standing liberal values in the Russian society. The paper deals with the history of liberalism interpreting Constitution as a document ensuring and enshrining the basic liberal values.

Keywords: social determinism, law, constitutional spirit, mentality, system of values, individual rights and freedoms, liberalism.

Сущность либерализма сводится к провозглашению прав и свобод отдельно взятой личности путем расширения ее возможностей и достижения благополучия и счастья. Основной метод либерализма - устранение всего, что может посягнуть или создать препятствие к свободе. Но либералы отдают себе отчет в том, что свободный человек способен к злу и анархии, поэтому действия либералов направлены на создание правового государственного порядка, ограничивающего абсолютный индивидуализм, апогеем которого является анархия. Установление либерального порядка возможно посредством учреждений, в которых человек действует по определенным правилам, при этом сводя к минимуму организационно-регламентирующую деятельность государства, сдерживающую предприимчивость отдельных лиц. Поэтому сильный гражданский строй является обязательным условием политической свободы как высшей ценности либерального государства, установление которого мыслилось в качестве цели политической борьбы в России.

Противовесом административной системе, основанной на централизации власти, выступает конституционный строй - синоним либерализма. Суть конституции заключается в обеспечении свободы от подавления государственной властью гражданского строя и утверждении индивидуалистических принципов, на которых этот строй покоится, и основных прав, которые этот строй воплощает. Концепция классического либерализма базируется на соотношении конституционного строя, действующего в рамках индивидуалистического либерального общественного порядка, и гражданского строя, гарантируемого судебной властью. При таком соотношении гражданского и конституционного строя возникает ограничение законодательной власти в пользу индивидуалистического гражданского порядка. В этих условиях принимаемые законы являются настоящим правом, так как они выражают волю народа. Полномочия конституции заключаются в гарантированном разделении власти, когда за каждой ее ветвью стоит общественный фактор, т. е. гражданское общество. На практике разделение власти помогает ограничить каждую ее ветвь и тем самым укрепить правопорядок в целом, установив общие правила, по которым организуется жизнь всего общества и без установления которых последнее не может существовать [1].

В основе любой конституции лежит гуманизация отношений в структуре «личность - государство», итогом которой выступает сильное гражданское общество и, как следствие, правовое государство в целом. Генезис и развитие гражданского общества постепенно приводят к установлению равенства между человеком и государством, тогда как регулятором этих отношений является закон. С одной стороны, закон формируется самим обществом, а с другой - под его действием устанавливаются правила для этого общества.

Опустив наиболее древние законодательные акты как прообраз самоорганизации общества, начнем рассматривать историю зарождения либерализма в России со времен правления Екатерины II. Ее рефрормы коснулись практически всех слоев общества - на заре своего правления она стремилась укрепить религиозную терпимость, «смягчить» уголовное право, обеспечить 
личную свободу дворян, облегчить положение крестьян. Либеральная программа нашла свое выражение в «Наказе», который был создан для Законодательной комиссии. Социальные изменения превращались в право через законы в виде единого планирования для всей страны, ограничения монополии предприятий, защиты частной собственности, возмещения убытков государством в случае их нанесения последним [2].

При Александре I по меньшей мере два видных общественных деятеля внесли существенный вклад в развитие тенденций либерализации общества. Граф Н.С. Мордвинов работал над законами, способствовавшими обретению материальной независимости государственными крестьянами. Он же боролся за неприкосновенность частной собственности [3]. М.М. Сперанский, обращаясь к императору в записке к документу «Введение к уложению государственных законов», ратовал за гарантированную охрану частной собственности, укрепление гражданского строя, соблюдение прав и свобод граждан и ограничение государственной власти [4].

Апогеем либерализма в царской России можно назвать Манифест об освобождении крестьян от 19 фревраля 1861 г. Александра II. Не углубляясь в детали этого документа, следует отметить, что в деле либерализации целой страны произошел огромный прорыв.

Из многовековой истории страны эпоха правления Николая II - самая либеральная. Об этом свидетельствуют его указ от 1903 г. об отмене круговой поруки в общине, манифест от 1904 г. о запрете на телесные наказания, осуществленный в 1906 г. перевод казенных земель в разряд частной собственности крестьян, допуск к государственной службе всех сословий. В октябре 1905 г. манифестом были расширены избирательные права, провозглашено равноправие религий и национальностей, учреждено выборное собрание с законодательными полномочиями. А 6 мая 1906 г. Николай II утвердил свод «Основных государственных законов Российской империи», который кардинально изменил государственное устройство, гарантировав разделение власти и полномочий между императором и российским парламентом. Первая российская конституция была подкреплена законами о печати (1905 г.), союзах и объединениях (1906 г.) [5].

Конечно, по отношению к европейскому устройству все эти либеральные течения можно было бы назвать всего лишь «избавлением от варварства». Но, принимая во внимание историю России, нельзя не признать, что государство сделало огромный шаг на пути к либерализму и его прямому следствию - подлинному конституционализму. Правда, последующие трагические события не дали закрепиться достигнутому в сознании граждан - либеральные ценности не стали для них ориентирами политической жизни.

В советский период истории, несмотря на наличие писаной конституции (первая принята в 1918 г.), были слабо развиты институты, способствовавшие защите личности. К тому же были весьма ограниченны возможности объективного научного анализа конституции. Правда, в 1920-х гг. вышли в свет комментарии к первой советской конституции М.А. Рейснера и Г.С. Гурвича, а еще через 20 лет С.Л. Ронин написал книгу, посвященную этой же тематике [6].

Несмотря на наличие конституции в советский период, можно назвать по меньшей мере два ключевых момента, которые, по сути, меняют роль конституции в ее либеральном понимании. Во-первых, исполнительная власть недостаточно ограничена правом, а во-вторых, права и свободы граждан ограниченны и слабо защищены. Так, если сравнить позиции, касающиеся правового положения личности, закрепленные в конституциях 1906 и 1918 гг., то в первой конституции им посвящена глава, а во второй - лишь две статьи, гарантирующие политические свободы в виде прав трудящихся на митинги и сборы и на создание союзов. Несомненно, существенно расширив социальные права трудящихся в виде закрепления прав на образование, труд, медицинское обеспечение, вторая конституция фактически исключила гарантию на права гражданские неприкосновенность личности и жилища, тайну переписки и пр. Кроме того, последствия войны и революции привели к полной нищете и разрухе и, соответственно, к фактической неспособности государства выполнить закрепленные в конституции обязательства.

Конституции 1924, 1936 и 1977 гг., по сути, продолжали намеченный курс 1918 г. Несмотря на предоставление гражданам равных прав на всеобщее, равное и прямое избирательное право при тайном голосовании, свободу слова, печати и неприкосновенности личности (что было продекларировано в Конституции 1936 г.), утвердить ценности либерализма в необходимом объеме в советском обществе так и не удалось, гражданское общество так и не укрепилось по отношению к действующей власти, не сформировалось в качестве серьезного фактора общественной жизни.

Итак, либерализм в России проходил долгий путь зарождения, иногда укрепляясь, но в основном подавлялся различными фракторами, как то: недовольство реформами со стороны влиятельных лиц, общая нестабильная обстановка в обществе, войны и прочее неблагоприятное стечение обстоятельств. История конституции в России как гаранта либеральных прав и свобод личности начинается с формирования земств, и это естественно, если учитывать огромную территорию страны, до дальних уголков которой трудно «добраться» действующей власти. 
Бесспорно, наиболее яркими всплесками либерализма в России можно назвать период царствования Александра I, освобождение крестьян при Александре II и время политических реформ Петра Аркадьевича Столыпина. В определенный момент истории конституционализм приблизился к «революционализму». Здесь, судя по всему, имеет место сугубо психологический аспект, можно даже сказать - особенность российского менталитета, не имеющего ограничивающей экстремизм грани баланса, где заканчивается либерализм и начинается террор [7].

Завершая статью, отметим, что в современном российском обществе либеральные права гарантированы и закреплены действующей Конституцией, которую в известной степени подготовил предшествующий русский либерализм. Но для политической практики и науки остаются открытыми вопросы: насколько общество готово к воплощению этих прав и в полной ли мере эти права реализуются.

\section{Ссылки:}

1. Леонтович В.В. История либерализма в России. М., 1995. 445 с.

2. Платонов С.Ф. Полный курс лекций по русской истории. Петроград, 1917 ; Сборник Императорского русского исторического общества. СПб., 1867-1916. Т. 43, 134.

3. Особое мнение адмирала Мордвинова. М., 2008. С. 35.

4. Корнилов А.А. Реформаторский план Сперанского // Корнилов А.А. Курс истории России XIX века. М., 1993. 448 с.

5. Карамзин Н.М. История государства Российского. М., 2010. 1024 с.

6. Гурвич Г.С. Основы советской Конституции. Смоленск, 1921 ; Рейснер М.А. Основы советской Конституции. М., 1920 ; Ронин С.Л. Первая советская Конституция (к истории разработки Конституции РСФСР 1918 года). М., 1948 ; Чистяков О.И. Конституция РСФСР 1918 г. М., 2003.

7. См.: Сочнев А. «В Гражданской войне не победил никто» [Электронный ресурc]. URL: https://lenta.ru/articles/2015/05/29/civilwar/ (дата обращения: 12.01.2017).

\section{References:}

Chistyakov, OI 2003, The 1918 Constitution of the RSFSR, Moscow, (in Russian).

Collection of the Imperial Russian Historical Society 1867-1916, St.-Petersburg, vol. 43, 134, (in Russian).

Gurvich, GS 1921, Fundamentals of the Soviet Constitution, Smolensk, (in Russian).

Karamzin, NM 2010, The history of the Russian State, Moscow, 1024 p., (in Russian).

Kornilov, AA 1993, 'Speransky's reform plan', in Kornilov, AA, Kurs istorii Rossii XIX veka, Moscow, 448 p., (in Russian).

Leontovich, VV 1995, The history of liberalism in Russia, 445 p., (in Russian).

Platonov, SF 1917, A full course of lectures on Russian history, Petrograd, (in Russian).

Reisner, MA 1920, Fundamentals of the Soviet Constitution, Moscow, (in Russian).

Ronin, SL 1948, The first Soviet Constitution (to the history of the drafting of the 1918 Constitution of the RSFSR), Moscow, (in Russian).

Sochnev, A 2017, "No one won the Civil War", viewed 12 January 2017, <https://lenta.ru/articles/2015/05/29/civilwar/>, (in Russian).

Special opinion of Admiral Mordvinov 2008, Moscow, p. 35, (in Russian). 